\title{
A Novel Approach on Role of Polymers Used In Sustained Release Drug Delivery System- A Review
}

\author{
M. Subramani ${ }^{1 *}$, Dr. N. Vekatashwaramurthy ${ }^{2}$, Dr. R. Sambathkumar ${ }^{3}$ \\ ${ }^{1}$ Assistant Professor, Department of Pharmaceutics, J.K.K. Nattraja College of Pharmacy, Kumarapalayam, Namakkal, Tamilnadu, \\ India \\ ${ }^{2}$ Head, Department of Pharmacy Practice, J.K.K. Nattraja College of Pharmacy, Kumarapalayam, Namakkal, Tamilnadu, India \\ ${ }^{3}$ Principal and Head, Department of Pharmaceutics, J.K.K. Nattraja College of Pharmacy, Kumarapalayam, Namakkal, Tamilnadu, \\ India
}

DOI: $10.36348 /$ sjmps.2021.v07i04.002 $\quad$ | Received: 28.02.2021 | Accepted: 01.04.2021 | Published: 05.04 .2021

*Corresponding author: M. Subramani

\section{Abstract}

Oral ingestion is the preferential route for various drugs, providing an acceptable technique to consummate both local likewise systemic effects. SRDDS designed to ease off drug at a fixed rate by upholding a constant drug level for a definite period of time with decrease side effects. The fundamental reasoning of SRDDS exemplifies the pharmacokinetic, pharmacodynamic and biopharmaceutical effects of a drug so that it utility is increased, reduced the side-effects and control the disease. Nowadays research and development are carried out on sustained release formulations due to its inherent benefits over conventional dosage form. The main objective of the review, we discuss the sustained release tablets, its rationale, challenges, advantages, disadvantages, various polymers used in the preparation, of these formulations. This system gets easy to adopt for designing to treat various diseases thereby it improves patient compliance.

Keywords: Sustained release drug delivery system (SRDDS), Polymers, Rationale, Merits, Demerits, Future treads.

Copyright () 2021 The Author(s): This is an open-access article distributed under the terms of the Creative Commons Attribution 4.0 International License (CC BY-NC 4.0) which permits unrestricted use, distribution, and reproduction in any medium for non-commercial use provided the original author and source are credited.

\section{INTRODUCTION}

The oral route is determiner often route used for administration of drugs, due to its route of administration offers flexibility in two dosage form design than most other routes [1]. Drug release may be defined as the process where the drug is impose to pharmacokinetics study like absorption, distribution, metabolism and excretion, thereby drug is available for the efficient pharmacological action [2]. A number of terms used to describe the oral dosage forms that represent modified release properties, which include delayed release, repeated action, prolonged release, sustained release, controlled release, controlled release and other [3]. Each Active Pharmaceutical Ingredient delivery system, is focused on eliminating the repeated changes in plasma drug concentration seen after the administration of conventional delivery systems [4, 5]. Oral drug delivery as the often utilized ease of administered among compared to all the ease of administration, employed for systemic delivery of the drug from different pharmaceutical products of different dosage forms. The oral route of administration gets popularity due to its unique advantages $[6,7]$. This article, make attempt to revisit the importance and recent advances in role of polymers in Sustained Release Drug Delivery System (SRDDS) treat various diseases thereby it improves patient compliance.

\section{SUSTAINED RELEASE DRUG DELIVERY SYSTEM:}

A sustained-release drug product is sustained release dosage forms designed to clemency a drug at a fixed rate by upholding a constant drug level for a definite period of time. Usually, the drug may be delivered in an initial therapeutic dose, followed by a slower and constant release [8]. They have certain advantages like increase the bioavailability of drugs, ease of administration often convenient, stability of the drug, maintain uniform drug concentration in plasma, reduce the gastrointestinal irritation and side effect, toxicity to be minimize [9], have some demerits like release rate are affected by different aspect as food and the amount of transit through the gut, high cost, high probability of drug tolerance and dumping [10], high rate of first pass metabolism, and poor invitro and invivo correlation [11]. 
Table-1: Parameters for dug selection parameter preferred value [12]

\begin{tabular}{|l|l|}
\hline Molecular weight/size & $<1000$ \\
\hline Solubility & $>0.1 \mathrm{mg} / \mathrm{ml}, \mathrm{pH} 1-7.8$ \\
\hline Apparent partition coefficient & High \\
\hline General absorbability & Form all GI segments \\
\hline Release & Should not be influenced by $\mathrm{pH}$ and enzyme \\
\hline
\end{tabular}

\section{RATIONALE OF DEVELOPING SUSTAINED RELEASE DRUG DELIVERY SYSTEM:}

1. To enhance the period of drug action.

2. To scale down the frequency and inter and intra subject variability.

3. To reduce the fluctuations in plasma level and drug toxicity.

4. To improve drug utilization and duration.

5. To reduce side effects and cost of treatment.

\section{ADVANTAGES:}

i) Patient Compliance:

Patient compliance is overblown by numerous factors, like knowledge of ailment process, patient trust in treatment, and apprehension of patient related to a strict treatment plan. In addition to awkwardness of therapeutic regimens, the cost of therapy and local or systemic side effect of the dosage form. This issue start out to some degree by allocates sustained release drug delivery system.

ii) Reduced "See-Saw" fluctuation

Drug concentration in the body shows 'see-saw' pattern often when the drug given in conventional drug dosage form. The sizes of these variances essentially depend upon drug kinetics such as the amount of absorption, distribution, elimination and dosing intervals $[13,14]$.

iii)
To treat a feeble condition less part of agitate drug is used in SRDDS. By reducing the total amount of drug, abate in systemic or local side effects are noticed. This would also lead to greater economy [15].

iv) Economy

The introductory cost of sustained release products is often furthermore of conventional dosage form because of the median cost of treatment above the long period of time [16].

Disadvantages of SRDDS:

(i) Highly expensive

(ii) Often poor bioavailability

(iii) Need for supplementary patient counseling and education.

(iv) Dose dumping [17]

(v) Often poor in vivo - in vitro correlation [18].

\section{POLYMERS}

Polymers are complicated and big molecules consistently with carbons building the backbone, differs from low weight molecular compounds. The small individual repeating units/molecules are known as monomers. A polymer with two different monomers is called as copolymer or homopolymer. It has characteristics like low density, good corrosion resistance, economical poor temperature resistance, and have transparent or in colors.

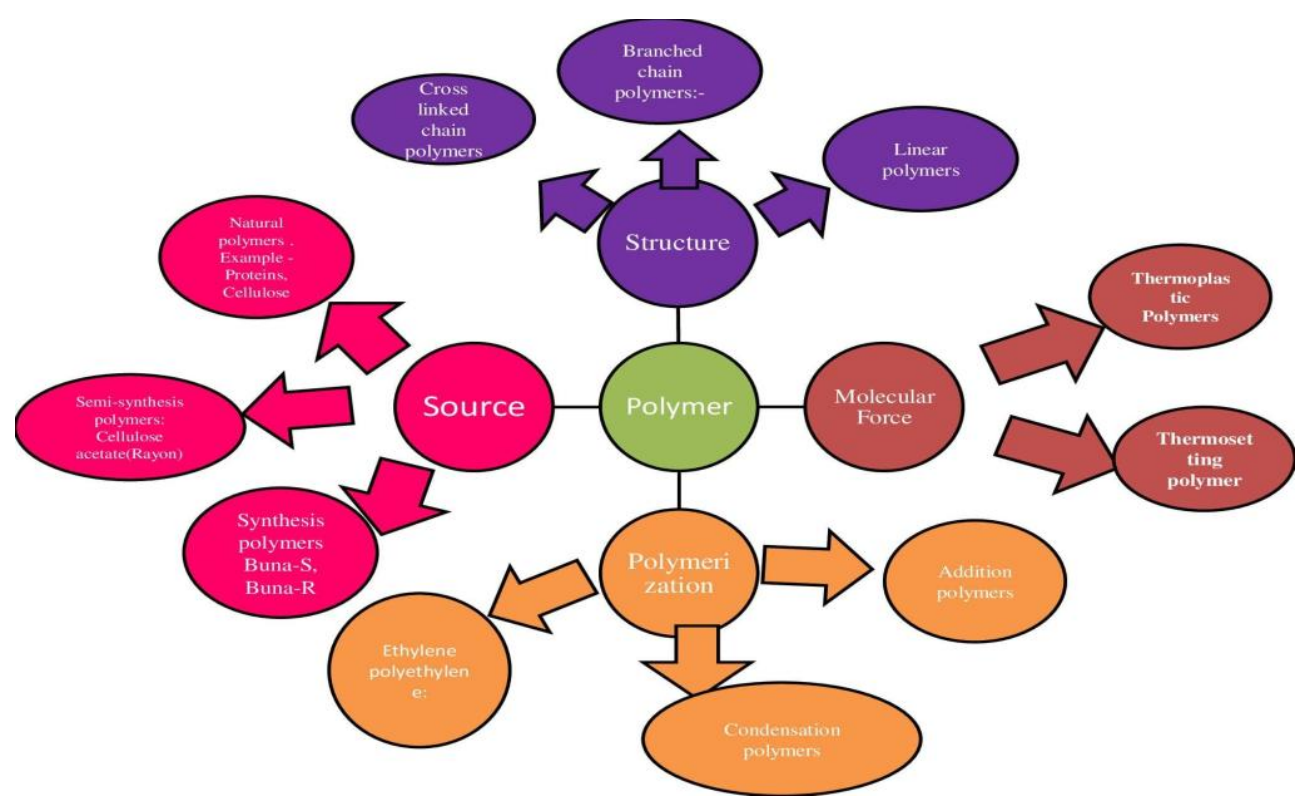


ROLE OF POLYMER IN PHARMACEUTICAL DRUG DELIVERY

Tablets

Polymers used as excipients in conventional immediate-release oral dosage forms for many years. Polymers including polyvinyl pyrrolidone and HPMC also find handling as binders that assistance the preparation of granules that improve the flow and convenient properties of tablets formulations prior to the tablet. Sporadically, dosage forms precondition be coated with a "non functional" polymeric film that one may protect a drug from degradation, mask the taste of a disagreeable drug or excipients, or increase the visual delicacy of the formulation without poignant the releasing rate of drug [19].

\section{Capsules}

Capsules are worn a proxy to tablets, trouble compressible materials, to mask the bitter taste or stepping up bioavailability. Gelatin used as a shell material for hard (two-piece) and soft(one- piece) capsules. HPMC has recently been evolve and believe as a surrogate material for the formulation of hard (twopiece) capsules.

\section{POLYMERS IN PHARMACEUTICAL DRUG DELIVERY SYSTEM:}

Rosin a film- forming biopolymer and its byproducts broadly used for film coating and microencapsulating materials to accomplish sustained drug release. They are more in cosmetics, chewing gums and dental varnishes. Rosin combination with polyvinyl pyrrolidone and dibutyl phthalate $(30 \% \mathrm{w} / \mathrm{w})$ contribute smooth film with magnifying elongation and tensile strength [20,21].

Chitin and Chitosan: Chitin a naturally mucopolysaccharide and it disintegrated by chitinase. Chitosan is a linear polysaccharide consisits of $\beta-(1-4)$ - linked D glucosamine (deacetylated unit) and $\mathrm{N}$ acetyl D glucosamine (acetylated unit). The significant property of chitosan in drug delivery it is positive charge under acidic conditions. This positive charge approach from the protoniation of its free amino groups. Lack of positive charge explain chitosan is precipitate in neutral and basic environments [22].

Zein: Zein is an alcohol-soluble protein emphasis in the endosperm tissue of Zea maize. Zein has been used as an edible coating for pharmaceuticals for two decades. Zein is an economical as well a substitute for rapid disintegrating synthetic and semi-synthetic film coatings currently used for the formulation of substrates that allow extrusion coating [23].

Collagen: Collagen is often found protein in mammals. It not only has been survey for use in various types of surgery, cosmetics and drug delivery, bio prosthetic implants, tissue engineering of multiple organs.

Polycaprolactone: Polycaprolactone (PCL) is biodegradable polyester along with around $60^{\circ} \mathrm{C}$ melting point Polycaprolactone is arranged by ringopening polymerization of zeta-caprolactone using a catalyst such as stannous octanoate. The more often use of polycaprolactone is the formulations of polyurethanes. Polycaprolactones transmit good water, oil, solvent and chlorine resistance to the polyurethane produced [24].

\section{POLYMERS USED IN SUSTAINED RELEASE DRUG DELIVERY SYSTEM}

There are number of polymers which may be used to formulate matrix tablets controlling by the physicochemical properties of the drug substance and drug release profile required. Polymers used for matrix tablets may be classified as [25-31]

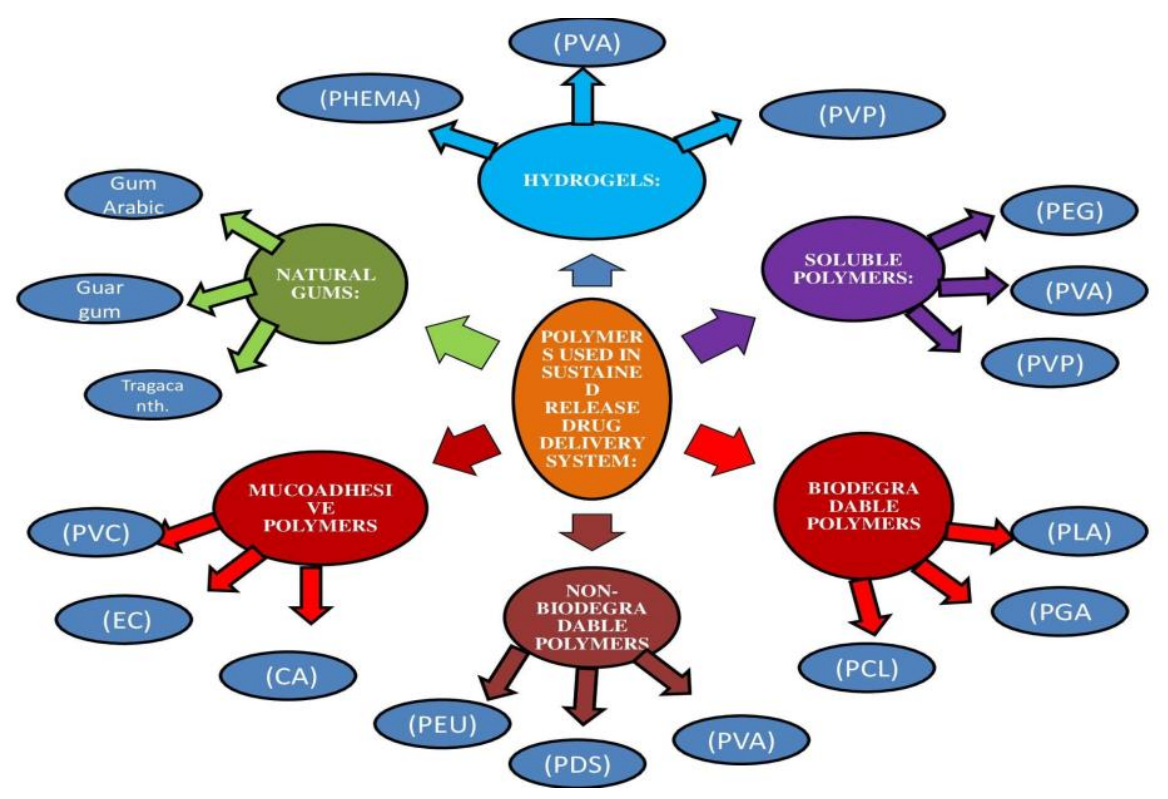




\section{Legends:}

PHEMA- Poly-hydroxyethyl methacrylate, PVACross-linked polyvinyl alcohol, PVP- Cross-linked polyvinylpyrrolidone, PEG- Polyethylene glycol, PVAPolyvinyl alcohol, PVP- Polyvinylpyrrolidone, PLAPolylactic acid, PGA- Polyglycolic acid, PCLPolycaprolactone PDS- Polydimethylsiloxane, PEU-
Polyether urethane, CA-Cellulose acetate, EC- Ethyl cellulose.

\section{ADVANCES IN HYBRID POLIMER - BASED MATERIALS FOR SUSTAINED RELAEASE DRUG DELIVERY SYSTEM [32]:}

Table-2: Blended polymers as pharmaceutical form for Drug Delivery Systems

\begin{tabular}{|l|l|l|l|l|}
\hline Sl. No & Polymeric blend & Form & Drug & Reference \\
\hline 01. & PEG-geletin & Nonoparticles & Ibuprofen & {$[33]$} \\
\hline 02. & PEG-geletin & Hydrogel & Ciproflaxin & {$[33]$} \\
\hline 03. & PLGA-gelatin & Nanofiber & Fenbufen & {$[33]$} \\
\hline 04. & PLGA-PEG & Micelle & Doxorubicin & {$[34]$} \\
\hline 05. & Chitosan-alginate & Beads & Bismuth Salicylate & {$[35]$} \\
\hline 06. & Chtin-Pluronic F108 & Microparticles & Paclitaxel & {$[36]$} \\
\hline 07. & Chitosan-glucomannan & Hydorgel & Chloramphenicol & {$[37]$} \\
\hline 08. & Chitosan-silk fibroin & Film & Theophylline & {$[38]$} \\
\hline 09. & Chitosan-silk fibroin & Film & Salicyclic acid & {$[38]$} \\
\hline 10. & Chitosan-silk fibroin & Film & Amoxicillin & {$[38]$} \\
\hline 11. & Chitosan-silk fibroin & Film & Sodium diclofenac & {$[38]$} \\
\hline 12. & Alginate -gelatin & Film & Ciproflaxin & {$[39]$} \\
\hline 13. & Alginate-zein & Film & Ibuprofen & {$[40]$} \\
\hline
\end{tabular}

Table-3: Some published works regarding biohybrid systems for sustained drug delivery, listed in terms of kind, activity, and encapsulation efficiency (EE\%)

\begin{tabular}{|l|l|l|l|l|}
\hline Sl. No & Biohybrid systems & Therapeutic molecule & EE\% & Ref \\
\hline 01. & SLN-PLGA-PEG-PLGA & 2-Methoxyestradiol & $91.3 \%$ & {$[41]$} \\
\hline 02. & PMMA-BSA & Camptothecin & $11.0 \%$ & {$[42]$} \\
\hline 03. & Liposome-Chitosan & Doxorubicin & $98.0 \%$ & {$[43]$} \\
\hline 04. & Liposome-cellulose & Quarcetin & $40.0 \%$ & {$[44]$} \\
\hline 05. & Liposome-Gel & Lidocaine & $21.6 \%$ & {$[45]$} \\
\hline 06. & Liposome-alginate & Benzocaine & $63.2 \%$ & {$[46]$} \\
\hline 07. & Cyclodextrin/liposome & Quercetin & $91.0 \%$ & {$[47]$} \\
\hline 08. & Cyclodextrin/PLGA & Oxaprozin & $62.0 \%$ & {$[48]$} \\
\hline 09. & NE-alginate/chitosan & Capsaicin & $68.0 \%$ & {$[49]$} \\
\hline 10. & SLN-hydorgel & Natural resin & - & {$[50]$} \\
\hline 11. & SLN-Polycarbophil & Cururmin & $88.1 \%$ & {$[51]$} \\
\hline 12. & SLN-PLGA & Flurbiprofen & $91.7 \%$ & {$[52]$} \\
\hline 13. & SLN-dextran & Ibuprofen & $99.1 \%$ & {$[53]$} \\
\hline 14. & SLN-PLGA & DNA & $93.1 \%$ & {$[54]$} \\
\hline 15. & NLC-Natural gum & Ondansetron & $29.9 \%$ & {$[55]$} \\
\hline 16. & Liposphere-PLGA & Donopezil Hydrochloride & - & {$[56]$} \\
\hline 17. & Lipid nanocapsules & Quercerin & $92.0 \%$ & {$[57]$} \\
\hline 18. & Lipid nanocapsules & Doxorubicin & $90.0 \%$ & {$[58]$} \\
\hline 19. & Liposphere-PLGA & Albumin & $90.8 \%$ & {$[59]$} \\
\hline 20. & SLN-PLGA & Salbutamol sulphate & $30.0 \%$ & {$[60]$} \\
\hline
\end{tabular}

\section{MECHANISMS OF DRUG RELEASE OF SRDDS $[61,62]$ Diffusion is rate limiting}

Diffusion may be defined as driving force where the movement of drug molecules occurs from high concentration in the tablet to lower concentration in gastro intestinal fluids [63]. This movement depends on diffusion pathway, diffusion coefficient, gastric acid, surface area and drug concentration gradient of the system. In practice we can follow either of the two methods, 

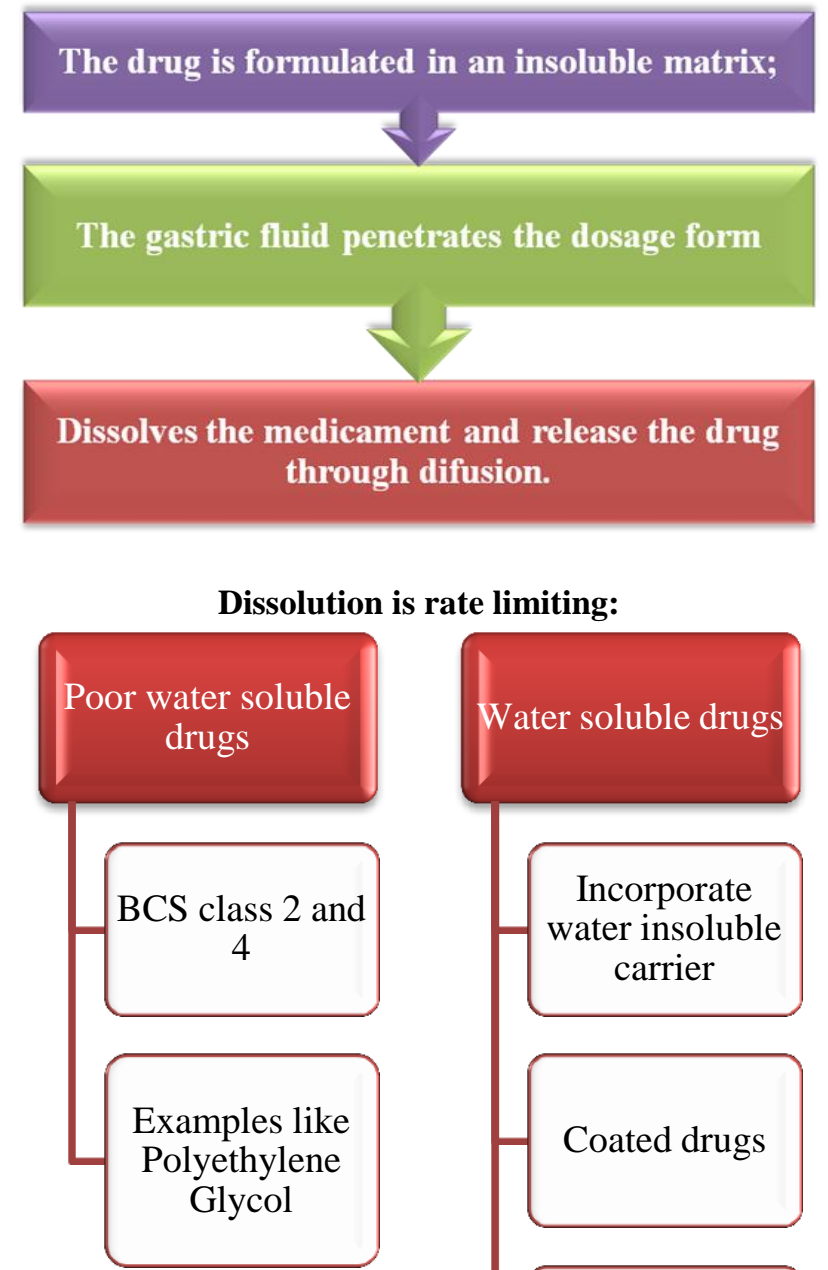

\section{Osmotic pressure is rate limiting}

Osmotic pressure is employed as the driving force to generate a constant release of drug. The delivery rate is constant provided that the excess of drug present inside the tablet. But, fate to deny to zero $[64,65]$.

\section{Release is controlled by ion exchange}

Ion exchangers are water in-soluble resinous materials that accommodate salt form in ganionicor cationic groups. While composing, the drug solution is

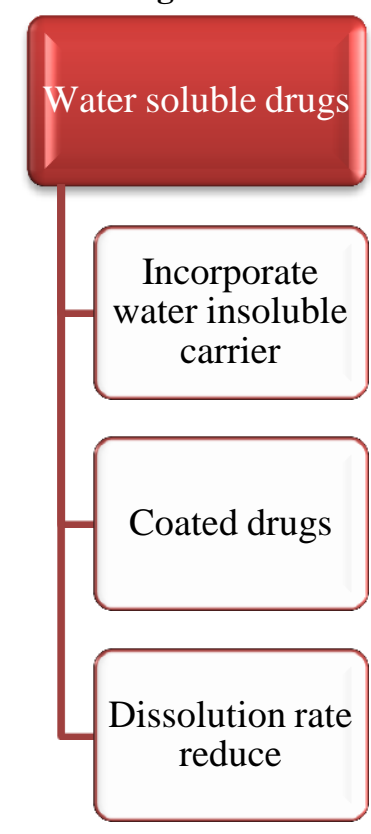

meld with resin and dried to form beads which are tableted. The rate of drug release hang the thread on a high concentration of charged ions in the gastrointestinal tract whereas; the Active Pharmaceutical Ingredients are traded and spread into the enclosing fluid. This mechanism depends upon the resin environment but not $\mathrm{pH}$ or enzyme on the absorption site [66, 67].

Resin+ - drug - + X - resin + - = X - + drug -

Conversely,

Resin- - drug + + Y + resin- - $=\mathrm{Y}++$ drug

Table-4: Sustained and Modified release formulations currently available in market [68-70]

\begin{tabular}{|l|l|l|}
\hline Example & Drug & Type \\
\hline Contifluo & Tamsolusin CRR beads & Diffusion an dissolution controlled beads \\
\hline Co-Amoxyclav ER tablet & Amoxicillin and potassium clavulanate & Matrix type CR bilayer tablets \\
\hline Cifran OD & Ciprofloxacin tablets $(500 \mathrm{mg} / \mathrm{g})$ & Effervescent matrix type floating tablets \\
\hline Desval ER tablets & $\begin{array}{l}\text { Divalproex sodium extended release tablets } \\
(250 / 500 \mathrm{mg})\end{array}$ & $\begin{array}{l}\text { Matrix type diffusion controlled ER } \\
\text { tablets }\end{array}$ \\
\hline
\end{tabular}




\section{FUTURE TRENDS}

The future of sustained-release drug products is promising, especially in the following areas that present high acceptability:

\section{Particulate systems}

The microparticle and nanoparticle access that draw in biodegradable polymers in which flawless drug-loaded particles via the Peyer's patches in the small intestine could be convient for delivery of peptide drugs that cannot, in often, be given orally [71].

\section{Chrono pharmacokinetic systems}

Oral sustained drug delivery with a pulsatile kindness regimen could satisfactory deliver drugs where a need exists to counter naturally transpire processes such as bacterial/parasitical growth patterns [72].

\section{Targeted drug delivery:}

Controlled drug delivery for oral route that targets regions in Gastro-Intestinal tract and clemency drugs only upon touching that site could offer effective treatment for assured disease states. E.g. colon-targeted delivery of Anti-neoplastics in the treatment of colon cancer [73].

\section{Mucoadhesive delivery:}

This is appropriate technique for the buccal and sublingual route, which can the rapid action and have greater bioavailability corresponding with simple oral delivery because it bypasses the first-pass metabolism in the liver [74].

\section{Conclusion}

The focus of this review article has been the formulation of sustained release drug delivery system, benefits of different types of Polymers, advantages, disadvantages, evaluation parameters. As compared to this system, may have better patient compliance, maintains plasma drug levels, reduce toxicity. The systems are very economical and these are designed by using the commonly available polymers. These systems are particularly useful, the patients those who are needed for a longer period of time.

\section{ACKNOWLEDGEMENTS}

I would like to thank the management and Principal of J.K.K. Nattraja College of Pharmacy College for providing all the facilities required to carry out my work.

Conflict of Interest: The authors declare to have no conflict of interest.

\section{REFERENCE}

1. Kamboj, S., Saroha, K., Goel, M., \& Madhu, C. (2015) Sustained Release Drug Delivery System:
An Overview. Journal of Pharmaceutics, 3(2), 204-215.

2. Wilde, C., Awad, M., Dua, H., Gandhewar, R., Chen, H. C., \& Amoaku, W. M. (2018). Epiretinal Membrane Surgery Outcomes in Eyes with Subretinal Drusenoid Deposits: A Case Control Study. Ophthalmology Retina, 2(12), 1218-1226.

3. Haan, P., \& Lerk, C. F. (2015). Oral controlled release dosage forms. A review, Pharm Weekbl Sci, 6(2), 57-67.

4. Singh, S., \& Pratap, A. (2014). A Brief Review on Sustained Release Matrix Tablets of Baclofen, Pharma Tutor; 2(12), 86-98.

5. Strasser, P., \& Teasdale, I. (2020). Main-Chain Phosphorus-Containing Polymers for Therapeutic Applications. Molecules, 25(7), 1716.

6. Souery, W. N., \& Bishop, C. J. (2018). Clinically advancing and promising polymer-based therapeutics. Acta Biomater. 67(1), 20-21.

7. Langer, R., \& Tirrell, D. A. (2004). Designing materials for biology and medicine. Nature. 428, 487-492.

8. Pandey, R., \& Sharma, A. (2003). Poly (DLlactide-co-glycolide) nanoparticle-based inhalable sustained drug delivery system for experimental tuberculosis, Journal of Antimicrobial Chemotherapy. 52, 981-986.

9. Pandey, A., Nikam, A. N., Mutalik, S. P., Fernandes, G., Shreya, A. B., Padya, B. S., \& Raychaudhuri, R. (2021). Architectured Therapeutic and Diagnostic Nanoplatforms for Combating SARS-CoV-2: Role of Inorganic, Organic, and Radioactive Materials. ACS biomaterials science \& engineering, 7(1), 31-54.

10. Barahuie, F., Dorniani, D., \& Saifullah, B. (2017). Sustained release of anticancer agent phytic acid from its chitosan-coated magnetic nanoparticles for drug-delivery system, International Journal of Nanomedicine. 12, 2361-2372.

11. Arjun, S., Ritika, S., Faraz, J., Sustained release drug delivery system: A review, International Journal of Research Publications. 3(9): 21-24.

12. Han, F. Y., \& Thurecht, K. J. (2016). Bioerodable PLGA-Based Microparticles for Producing Sustained-Release Drug Formulations and Strategies for Improving Drug Loading, Front. Pharmacol, 1(2), 101- 105.

13. Boniferoni, M. C., Rossi, S. (1995). Viscoelasteic properties of gels. Int J Pharm Sci, 117, 41-48.

14. Patel, K. K., \& Patal M. S. (2012). An overview: extended release matrix technology. Int $\mathbf{J}$ Pharm Chem Sci, 1(2), 828-829.

15. Jaimini, M., \& Kothari, A. (2012). Sustained Release Matrix Type Drug Deliery System: Journal of Drug Delivery and Therapeutics. 2(6), 72-76.

16. Jianxian, C., Saleem, K., Ijaz, M., Ur-Rehman, M., Murtaza, G., \& Asim, M. H. (2020). Development and invitro Evaluation of Gastroprotective Aceclofenac-loaded Self-emulsifying 
Drug Delivery System. International journal of nanomedicine, 15, 5217-5226.

17. Chibueze, I., Emenike, A. R., \& Oduola. (2017). Formulation And Evaluation Of Finasteride Sustained-Release Matrix Tablets Using Different Rate Controlling Polymers. Universal Journal of Pharmaceutical Research. 1(2), 16-18.

18. Shah, M., Ali, A., Aslam, H., \& Niaz, K. (2017). Compresion of antidislipiemic potential of 80 milligrams of fenofibrated with 8 gram of Nigella sativa seeds daily. Universal Journal of Pharmaceutical Research. 2(6):50-52.

19. Longer, M. A., Chng, H. S., \& Robinson, J. R. (2015). Bioadhesive polymers as platforms for oral controlled drug delivery III: oral delivery of chlorothiazide using a bioadhesive polymer, $\mathbf{J}$ Pharm Sci, 74(4), 406-408.

20. Park, K., \& Robinson, J. R. (1984). Bioadhesive polymers as platforms for oral- controlled drug delivery: method to study bioadhesion, Int $\mathbf{J}$ Pharm, 19, 107-09.

21. Chang, H. S. (2018). Bioadhesive polymers as platforms for oral controlled drug delivery II: synthesis and evaluation of some swelling, waterinsoluble bioadhesive polymers, J Pharm Sci, 74(4), 399-402.

22. Harris, D., Fell, J. T., Sharma, H. L., \& Taylor, D. C. (1990). Gastrointestinal transit of potential bioadhesive formulations in man: a scintigraphic study. J Controlled Release, 12, 45-48.

23. Leung, S., \& Robinson, J. R. (2018). Polymer structure features contributing to Mucoadhesion II. J Controlled Release, 12, 187-189.

24. Timmermans, J., \& Moes, A. J. (1990). How well do floating dosage forms float? Int J Pharm, 62, 207-208.

25. Jain, S., Yadav, S. K., \& Patil, U. K. (2008). Preparation and evaluation of sustained release matrix tablet of furosemide using natural polymers. Res J Pharm Tech. 1:37, 4-6.

26. Khan, A. B., \& Nanjundaswamy, N. G. (2009). Formulation and evaluation of sustained release matrix tablets of propranolol hydrochloride using carboxy methyl guar as a rate sustaining polymer. Arch Pharm Sci Res. 1(2) 203-06.

27. Patel. K., Rakesh, P., Avani, F., \& Madhabhai, M. (2005). Formulation and evaluation of mucoadhesive glipizide microspheres. AAPS Pharmaceutical Science and Technology. 6: 49-55.

28. Radhika, P. R, Pal, T. K., \& Sivakumar, T. (2009). Formulation and evaluation of sustained release matrix tablets of glipizide. Iranian J Pharm Sci. 5: 205-14.

29. Shah, P., \& Shelat, P. (2010). Design evaluation of matrix tablets containing a natural polysaccharide as a carrier to optimize active drugs, (NSAIDS) absorption profile for bed time administration (chronotherapeutic delivery). Int $\mathbf{J}$ Pharm Res. 2, 52-61.
30. Phacchamud, T. (2008). Effect of particle size of chitosan on drug release from layered matrix system comprising chitosan and xanthan gum. Thai Pharm Health Sci J, 3, 1-11.

31. Marroum, P. J.

(1997).

Bioavailability/Bioequivalence for Oral controlled release products, Controlled release drug delivery systems: Scientific and Regulatory Issues. Fifth International Symposium on Drug Development, East Brunswick, NJ. 15-25.

32. Foox, M., \& Zilberman, M. (2015). "Drug delivery from gelatin-basedsystems," Expert Opinion on Drug Delivery, 12(9), 1547-1563, 2015.

33. Joglekar, M., \& Trewyn, B., G. (2013). Polymerbased stimuliresponsive nanosystems for biomedical applications, Biotechnology Journal, 8(8), 931-945.

34. Xu, Y., Zhan, C., Fan, L., Wang, L., \& Zheng, H. (2018). Preparation of dual crosslinked alginatechitosan blend gel beads and in vitro controlled release in oral site-specific drug delivery system. International Journal of Pharmaceutics, 336(2), 329-337.

35. Sinha, V. R., Singla, A. K., \& Wadhawan S., (2004). "Chitosan microspheres as a potential carrier for drugs," International Journal of Pharmaceutics, 274, 1, 1-33.

36. Yu, H., Lu, J., \& Xiao, C. (2007). "Preparation and properties of novel hydrogels from oxidized konjac glucomannan cross-linked chitosan for in vitro drug delivery," Macromolecular Bioscience, 7(9) 1100-1111.

37. Rujiravanit, R., Kruaykitanon, S., Jamieson, A. M., \& Tokura, S. (2018). "Preparation of Crosslinked Chitosan/Silk Fibroin Blend Films for Drug Delivery System," Macromolecular Bioscience, 3(10) 604-611.

38. Dong, Z., Wang, Q., \& Du, Y. (2006). Alginate and gelatin blend films and their properties for drug controlled release. Journal of Membrane Science. 280, 1-2, 37-44.

39. Alcantara, A., C., S., Aranda, P., Darder, M., \& Ruiz, E. (2010). "Bionanocomposites based on alginate-zein layered double hydroxide materials as drug delivery systems," Journal of Materials Chemistry, 20(42), 9495-9504.

40. Guo, X., Cui, F., Xing, Y., Mei, Q., \& Zhang, Z. (2011). Investigation of a new injectable thermosensitive hydrogel loading solid lipid nanoparticles, Die Pharmazie, 66(12), 948-952.

41. Ge, J., Neofytou, E., Lei, J., Beygui, R. E., \& Zare, R. N. (2012). Protein polymer hybrid nanoparticles for drug delivery. Small, 8(23), 3573-3578.

42. Ren, S., Dai, Y., \& Li, C., (2016). "Pharmacokinetics and pharmacodynamics evaluation of a thermosensitive chitosan based hydrogel containing liposomal doxorubicin," 
European Journal of Pharmaceutical Sciences, 92, 137-145.

43. Park, S., Lee, M. H., Kim, S., \& Yu, E. R. (2013). Preparation of quercetin and rutin-loaded ceramide liposomes and drug releasing effect in liposome-in-hydrogel complex system. Biochemical and Biophysical Research Communications, 435(3), 361-366.

44. Franz-Montan, M., Baroni, D., \& Brunetto, G. (2015). Liposomal lidocaine gel for topical use at the oral mucosa: Characterization, in vitro assays and invivo anesthetic efficacy in humans," Journal of Liposome Research, 25(1), 11-19.

45. Cohen, R., Kanaan, H., Grant, G. J., \& Barenholz, Y. (2012). Prolonged analgesia from Bupisome and Bupigel formulations: From design and fabrication to improved stability, Journal of Controlled Release, 160(2), 346-352.

46. Maestrelli, F., Rabasco, A. M., Ghelardini, C., \& Mura, P. (2010). New "drug-in cyclodextrin-in deformable liposomes" formulations to improve the therapeutic efficacy of local anaesthetics," International Journal of Pharmaceutics, 395(1), 222-231.

47. Mura, P., Maestrelli, F., Cecchi, M., Bragagni, M., \& Almeida, A. (2010). Development of a new delivery system consisting in 'drug in cyclodextrinin PLGA nanoparticles'. Journal of Microencapsulation, 27(6), 479-486.

48. Choi, A. J., Kim, C. J., Cho, Y. J., Hwang, J. K., \& Kim, C. T. (2011). Characterization of Capsaicin-Loaded Nanoemulsions Stabilized with Alginate and Chitosan by Self-assembly. Food and Bioprocess Technology, 4(6), 1119-1126.

49. Hao, J., Wang, X., Bi Y. (2014). Fabrication of a composite system combining solid lipid nanoparticles and thermosensitive hydrogel for challenging ophthalmic drug delivery. Colloids and Surfaces B: Biointerfaces. 114, 111-120.

50. Hazzah, H. A., Farid, R. M., Nasra, M. M. A., ElMassik, M. A., \& Abdallah, O. Y. (2015). Lyophilized sponges loaded with curcumin solid lipid nanoparticles for buccal delivery: Development and characterization. International Journal of Pharmaceutics, 492, (1-2), 248-257.

51. Jain, S. K., Chourasia, M. K., \& Masuriha R. (2015). "Solid lipid nanoparticles bearing flurbiprofen for transdermal delivery," Drug Delivery: Journal of Delivery and Targeting of Therapeutic Agents, 12(4), 207-215.

52. Paolicelli, P., Cerreto, F., \& Cesa S., (2009). "Influence of the formulation components on the properties of the system SLN dextran hydrogel for the modified release of drugs," Journal of Microencapsulation, 26(4), 355-364.

53. Zhu, L., Xie, S., Dong, Z., Wang, X., Wang, Y., \& Zhou, W. (2011). "Effects of poly (lactic-coglycolic acid) on preparation and characteristics of plasmid DNA-loaded solid lipid nanoparticles," IET Nanobiotechnology, 5(3), 79-85.
54. Devkar, T. B., Tekade, A. R., \& Khandelwal, K. R. (2014). "Surface engineered nanostructured lipid carriers for efficient nose to brain delivery of ondansetron $\mathrm{HCl}$ using Delonix regia gum as a natural mucoadhesive polymer," Colloids and Surfaces B: Biointerfaces, 122, 143-150.

55. Ma, T., Wang, L., Yang, T., \& Wang, D. (2014). "PLGA lipid liposphere as a promising platform for oral delivery of proteins," Colloids and Surfaces B: Biointerfaces, 117, 512-519.

56. Hatahet, T., Morille, M., Shamseddin, A., \& Aubert-Pouessel. (2017). Dermal quercetin lipid nanocapsules: Influence of the formulation on antioxidant activity and cellular protection against hydrogen peroxide," International Journal of Pharmaceutics, 518(1-2), 167-176.

57. Antonow, M. B., Asbahr, A. C., \& Raddatz, P. (2017). Liquid formulation containing doxorubicin-loaded lipid-core nanocapsules: Cytotoxicity in human breast cancer cell line and invitro uptake mechanism. Materials Science and Engineering C: Materials for Biological Applications, 76, 374-382.

58. Hong, Y., Hu, Q., \& Yuan, H. (2016). "Effect of PEG2000 on drug delivery characterization from solid lipid nanoparticles," Die Pharmazie, 61(4), 312-315.

59. Jeon, H. S., Seo, J. E., \& Kime M. S. (2013). A retinyl palmitate-loade solid lipid nanoparticle system: Effect of surface modification with dicetyl phosphate on skin permeation in vitro and antiwrinkle effect in vivo, International Journal of Pharmaceutics, 452(1-2), 311-320.

60. Gomez- Romero, P. (2001). Hybrid OrganicInorganic Materials-In Search of Synergic Activity, Advanced Materials, 13(3), 163-174.

61. Varma, M. V. S., Kaushal, A. M., \& Garg, S. (2004). Factors affecting mechanism and kinetics of drug release form matrix-based oral controlled drug delivery systems. Am J Drug Deliv. 2:43-47.

62. Shah, K. U. (2012). Regulating Drug Release Behavior and Kinetics from Matrix Tablets Based on Fine Particle-Sized Ethyl Cellulose Ether Derivatives: An In Vitro and In Vivo Evaluation. Scientific world journal. 1(2), 21-24.

63. Sarika, P., Ashutosh, B, Deepak, S. (2017). Sustained Release Matrix Technology And Recent Advance In Matrix Drug Delivery System: A Review. International Journal of Drug Research and Technology, 3(1), 8-12.

64. Patiwala, M. S. M., Jethara, S., \& Patel, M. R. (2015). Recent trends in sustained release oral drug delivery system: A Promising approach. World Journal of Pharmaceutical Research, 1(4), 526-552.

65. Strandgarden, K., \& Hoglund, P. (1999). Dissolution rate-limited absorption and complete bioavailability of roquinimex in man. Biopharm Drug Dispos. 20(7):347-54 
66. Bathool, A., \& Gowda, D. V. (2012). Development and evaluation of microporous osmotic tablets of diltiazem hydrochloride: J Adv Pharm Technol Res. 3(2): 124-129.

67. Chaudhari, A. R., Nayan Bhushan, P., \& Bakliwal, S. P. (2012). Novel sustained release drug delivery system: A review. Pharma Research. 8. 80-97.

68. Khodaverdi, E., Tekie, F. S., Mohajeri, S. A., Ganji, F., Zohuri, G., \& Hadizadeh, F. (2012). Preparation and investigation of sustained drug delivery systems using an injectable, thermosensitive, In-situ, forming hydrogel compose of PLGA-PEG-PLGA, Journal of pharmaceutics. 2: 590-600.

69. Gupta, A. K., Mittal, A., \& Jha, K. K. (2012). Fast Dissolving tablet - A review, the pharmaceutical innovation, International Journal of Biomedical Sciences, 1:1-7.

70. Gupta, M. M., \& Ray, B. A. (2012). Review on Sustained Release Technology. International Journal of Therapeutic Application, 8, 1-23.

71. Seipmann, J., \& Peppas, N. A. (2012). Modelling of drug release form delivery systems based on Hydroxy propylmethyl Cellulose (HPMC). Adv Drug Delive Rev, 64: 163-174.

72. Grund, S., \& Bauer, M. (2011). Polymers in Drug Delivery-State of the Art and Future Trends: Advanced Engineering Materials, 13(1), B61-B68.

73. Belali, M., \& Wathoni, N. (2019). Advances in orally targeted drug delivery to colon: J Adv Pharm Technol Res. 10(3): 100-106. 